\title{
Proposal of the Composite Footbridge for the Military Application
}

\author{
Aleksandra BAK ${ }^{1}$, Ryszard CHMIELEWSKI ${ }^{1}$, Pawel MUZOLF ${ }^{1}$, Marcin MALEK ${ }^{1}$, \\ Marcin WACHOWSKI ${ }^{2}$
}

\author{
${ }^{1}$ Faculty of Civil Engineering and Geodesy, Military University of Technology, Address: Gen. \\ Urbanowicza St. 2, 00-908, Warsaw, Poland. \\ ${ }^{2}$ Faculty of Mechanical Engineering, Military University of Technology, Address: Gen. \\ Urbanowicza St. 2, 00-908, Warsaw, Poland.

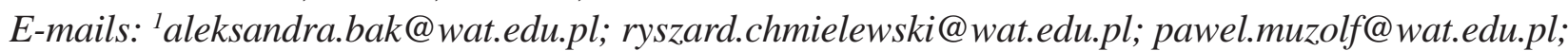 \\ ²marcin.wachowski@wat.edu.pl
}

\begin{abstract}
The article presents the methodology of modeling a footbridge structure made of a composite material. A lightweight composite footbridge is proposed, which may find application for small-span crossing of the rivers and other terrain obstacles for military purposes. The construction is characterized by lightweight, easiness of assembly and universal application in various location and conditions. The numerical model of the structure was developed based on a 6-meter prototype, for which a reinforcement was proposed and a detailed numerical analysis was carried out for the 18-meter version.
\end{abstract}

KEY WORDS: laminated composite materials, footbridge, hand - operated assembly

\section{Introduction}

The durability of composite materials, their competitive price and easiness of design and shape forming cause that many attempts have been made to apply them successfully to the construction of bridges $[1,2]$. One of the possible applications of this type of material, without the necessity of its assembly with elements ensuring spatial stiffness of the structure, is the construction of footbridges. Limitation to pedestrian traffic is dictated by operational safety due to the low construction weight and the susceptibility of this type of material to the formation of deformations and displacements of the structure. In the case of applications for car or railway traffic, it would be necessary to use an assembly with rigid elements, for example a reinforced concrete deck plate. The carried - out, initial numerical calculations and engineering analysis show that it is possible to use this type of construction while performing certain modifications in relation to the prototype solution. This solution, as a prototype with a 6-meter span, was developed by the Aircraft Repair and Production Department from Bielsko-Biała [3] - Fig. 1.

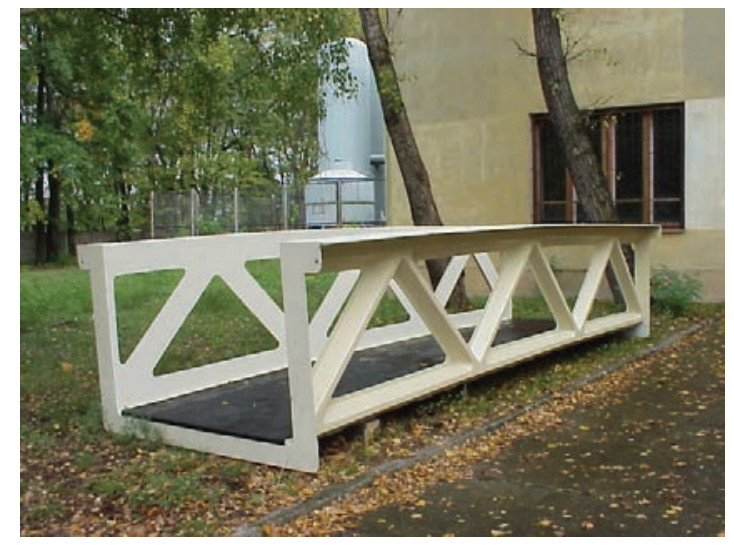

Fig. 1. The prototype of the composite footbridge section [3]

The application of this type of footbridges is justified for the performance of fast crossing over terrain obstacles of small spans. In particular, it is possible to utilize them in military operations to increase the mobility of troops. Moreover composite footbridges can be used in small municipalities and everywhere where small watercourses or other obstacles such as excavations hinder pedestrian traffic. The analyzed spans of composite footbridges is sufficient for the temporary overcoming of pedestrian difficulties and inconveniences also in urban areas in the case of tedious excavations and earthworks as well as road infrastructure repairs. 
The methodology of modeling a lightweight, composite footbridge structure is presented in this paper. The numerical model of the structure was developed based on a 6-meter prototype, for which a reinforcement was proposed and a detailed numerical analysis was carried out for the 18-meter version.

\section{Numerical Model of the Composite Footbridge}

Based on the results of the analysis of the 6 meters span prototype, a 18 meters span model of the composite footbridge was developed. Compared to the prototype section, two reinforcements and improvements were proposed. The first modification consists in stiffening the extreme section by using a wider floor beams at the ends of the structure - Fig. 2 . The second reinforcement in the form of two internal half-frames is proposed to ensure greater stability of the structure. These is achieved by increasing the thickness of the girders' cross braces and reinforcing the section of the bridge deck - Fig. 3. This was done both by extending the two deck fins to the end of the lower horizontal beam as well as increasing their thickness.

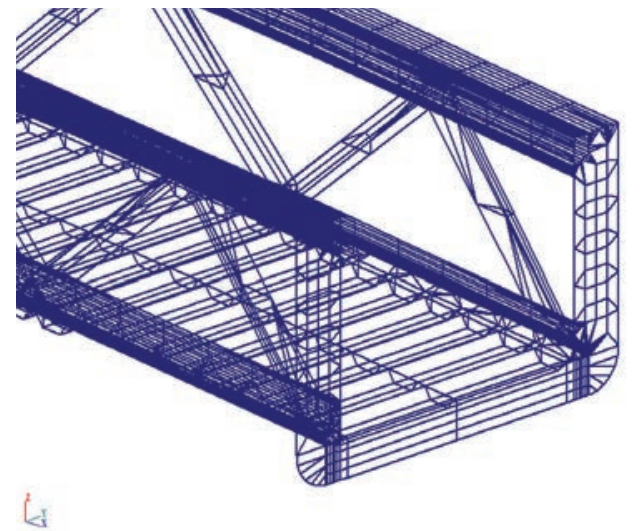

Fig. 2. The improvement of the prototype in the form of application a wider floor beams at the ends of the structure

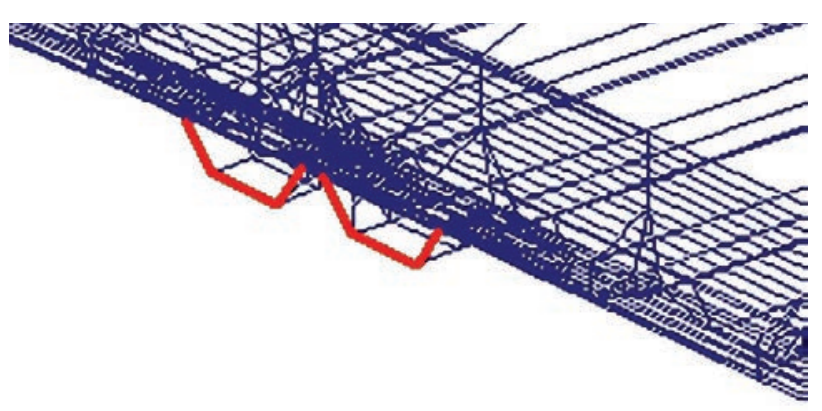

Fig. 3. Reinforcement of the middle section of the footbridge

After developing the design of the reinforcement of the original 6-meter section of the prototype bridge, the conceptual design of the composite footbridge with a span of 18 meters were carried out. The structure consist of three sections of a 6-meter. The axis of the bridge deck describes an arc having a radius of $90 \mathrm{~m}$, which give a $0.45 \mathrm{~m}$ preliminary rise of arch. Deck has a width of $1.60 \mathrm{~m}$. The height girders is $1.16 \mathrm{~m}$ (measured to the level of the deck).

The numerical model has been developed as a 3D, deformable, shell finite element model described on the cylinder axis - Fig. 4.

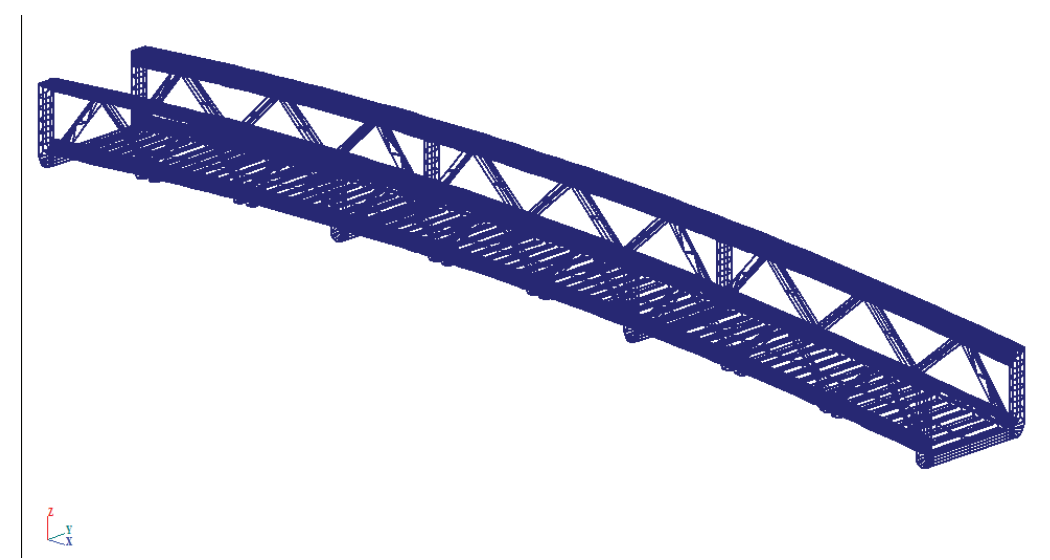

Fig. 4. Numerical model of an 18-meter span footbridge

The basic system of computational loads for bridges and a system of characteristic loads for checking serviceability limit states were used for calculations. The following loads were applied:

- deadweight of the footbridge, generated automatically by the software,

- the weight of the pavement on the deck in the form of a uniformly distributed load on the deck,

- the load of pedestrian crowd according to EC1[4] for simulating soldiers' passage,

- wind load according to wind pressure recommended in [5].

Using the appropriate coefficients, all loads were combined into normative combinations for the DA 2 calculation approach. 


\section{Results of the Numerical Model Calculation and its Analysis}

The results obtained in the numerical model were compiled in the form of the stress distribution maps in the main elements of the analyzed composite footbridge. The first is the most strenuous top flange of the truss girder. Figure 5 shows the reduced von Mises stresses in this element, while in Fig. 6 the principal stresses along the compressed fibers are presented. These values are very similar to each other, which is the effect of adopting an arched scheme of the spar girders.

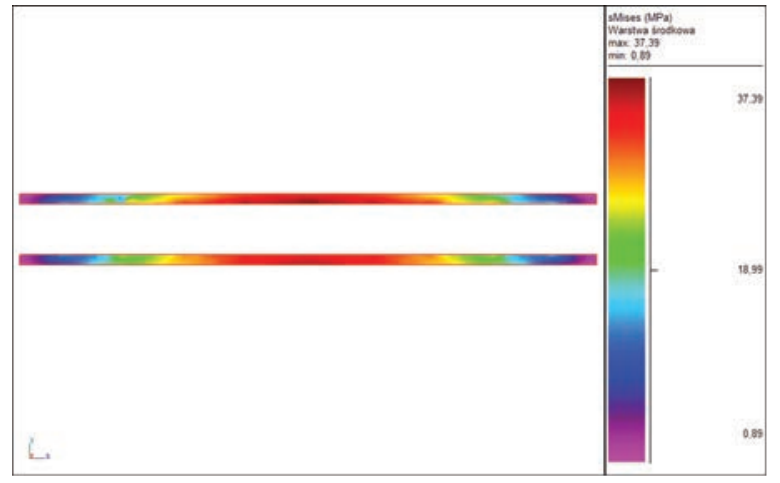

Fig. 5. The reduced von Mises stresses in the top flange of the truss girder

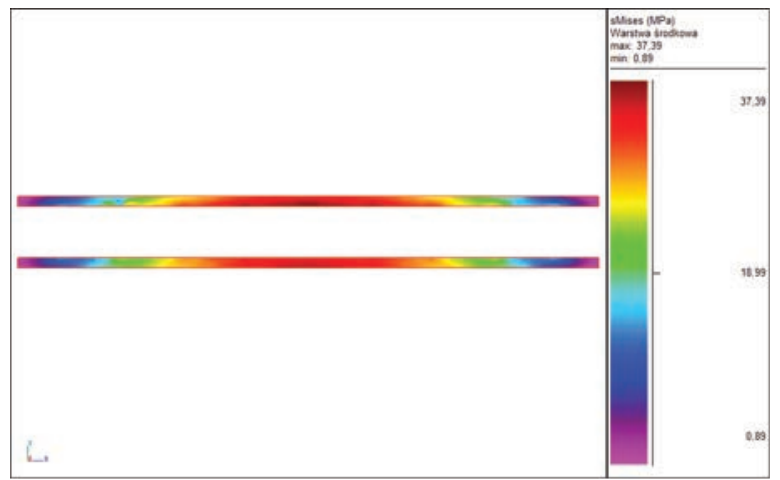

Fig. 6. The principal stresses in the top flange of the truss girder

The obtained values of stresses do not exceed the permissible value, i.e. $400 \mathrm{MPa}$ in any of the analyzed elements of the composite footbridge structure. The maximum material effort is less than $10 \%$ of the limit values. More unfavorable values are obtained for serviceability limit states. The obtained values of horizontal displacements from the crowd load of pedestrians are presented in Table 1, while horizontal displacements for wind load amounts to $0.5532 \mathrm{~cm}$.

Maximum vertical displacements of the footbridge structure

Table 1

\begin{tabular}{|c|c|}
\hline Node number & Vertical displacement $[\mathrm{cm}]$ \\
\hline 15773 & $-6,5401$ \\
\hline 15766 & $-6,2433$ \\
\hline 614 & $-6,2312$ \\
\hline 15781 & $-5,8314$ \\
\hline 15758 & $-5,6340$ \\
\hline 15789 & $-5,0091$ \\
\hline 731 & $-4,9421$ \\
\hline 15707 & $-4,5820$ \\
\hline 15728 & $-4,5808$ \\
\hline 15695 & $-4,5759$ \\
\hline
\end{tabular}

According to the Polish standard [6], the displacement values are about $65 \%$ of the admissible values, which indicates the proper design of the construction itself and effective transverse stiffening of the prototype. Considering the stiffening elements, the maximum effort was obtained in the lattice girders. Fig. 7 shows a map of the maximum principal stresses of the reinforced deck rib, while in Fig. 8 the maximum stresses in the reinforced flanges of the central module are shown. 


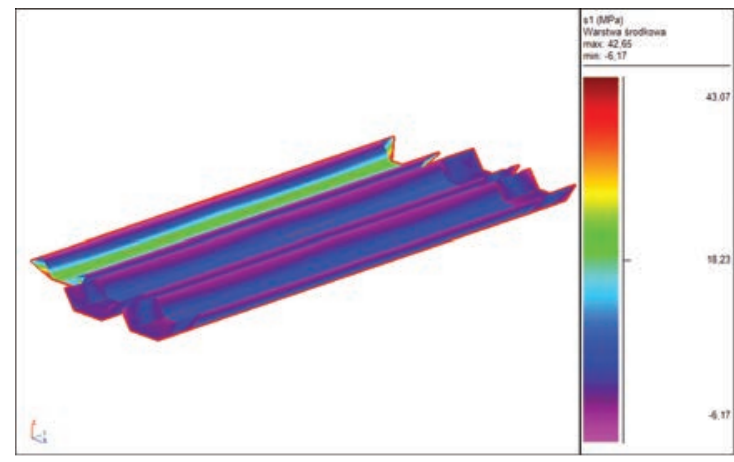

Fig. 7. The principal stresses in the reinforced deck rib

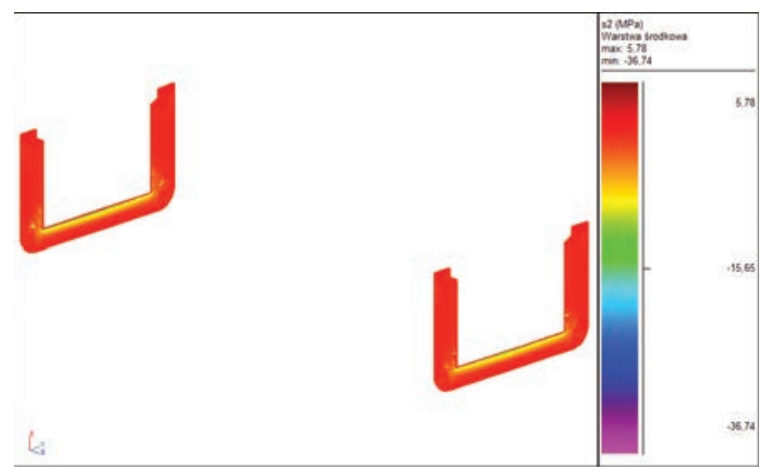

Fig. 8. The principal stresses in the reinforced flanges of the central module

\section{Conclusions}

The proposed solution for the improvement of the composite footbridge fulfills requirements of the standard values of loads in relation to pedestrian traffic. This is proven by carried out numerical calculation as well as the analysis made in this paper. Subsequently, it is proposed to produce reinforced constructions, to operate them under the load of pedestrians and to observe the practical use of these solutions, in particular for military applications to increase the mobility of troops. The operational value of the proposed solution is the long-term durability and life-cycle of the footbridge in the original technical condition without the use of any anti-corrosion protection. However, it should be emphasized that the analysis omits unrecognized fatigue conditions of material behavior under operating load.

The application of composite materials in bridge construction brings tangible results, especially in reinforcing existing concrete bridges [7]. Currently, the practical application of composite materials in main elements of engineering structures is more often observed in the area of civil engineering $[1,2,8,9]$. The proposed structure, apart from being used as a typical footbridge, is also possible to be used as working platforms and crossings for temporary overcoming of small terrain and water obstacles, particularly by military troops. Additionally, it enables safe crossing of excavations in the case of earthworks for civilian pedestrians. That types of footbridges also ensure the continuity of pedestrian communication and make it possible to minimize the troublesome bypasses of places inaccessible to pedestrian traffic.

\section{References}

1. Siwowski T. , Kulpa T., Poneta P. Badania nad zastosowaniem kompozytów FRP do budowy mostów w Polsce, Materiały Budowlane nr 11, 2014, p. 56-60.

2. Siwowski T. , Rajchel M., Wiater A. Pierwszy polski most kompozytowy w badaniach, Builder, 2017, p. 98-102

3. Zbornik $\mathrm{z} 9$ verdeckiej konferencie s medzinarodnou ucastou, Risenie krizowych situacii $\mathrm{v}$ specifickom prostredi, Zilina 2004, p. 175-178.

4. PN-EN 1991-1-1: Eurocode 1: Actions on structures - Part 1-1: General actions - Densities, self-weight, imposed loads for buildings.

5. PN-EN 1991-1-4: Eurocode 1: Actions on structures - Part 1-4: General actions - Wind actions.

6. PN-89/S-10050: Bridges, Steel structures, Requirements and tests - Polish standard.

7. Siwowski T., Radomski W. Pierwsze krajowe zastosowanie taśm kompozytowych do wzmocnienia mostu, Inżynieria i Budownictwo 54 (1998), p. 382 - 388.

8. Zobel H., Karwowski W., Wróbel M. Kładka z kompozytu polimerowego zbrojonego włóknem szklanym, Inżynieria i Budownictwo 59 (2003), p. 107-108.

9. Grotte B., Karwowski W., Mossakowski P., Wróbel W., Zobel H., Żółtowski P. Stalowa łukowa kładka dla pieszych z podwieszonym pomostem z kompozytów polimerowych nad drogą S-11 pod Kórnikiem., Inżynieria i Budownictwo 65 (2009), p. 69-73. 